medRxiv preprint doi: https://doi.org/10.1101/2020.06.01.20119719; this version posted June 2, 2020. The copyright holder for this preprint

(which was not certified by peer review) is the author/funder, who has granted medRxiv a license to display the preprint in perpetuity.

It is made available under a CC-BY 4.0 International license .

\title{
Cardiac Adverse Events of Immune Checkpoint Inhibitors in Oncology Patients: A
}

\section{Systematic Review and Meta-Analysis}

Nso Nso Vialli, M.D., M.P.H. ${ }^{\mathrm{a}^{*}}$, Daniel Antwi-Amoabeng, M.D., M.Sc. ${ }^{\mathrm{b} *}$, Bryce D. Beutler,

M.D. ${ }^{\mathrm{b}}$, Mark B. Ulanja, M.D., M.P.H. ${ }^{\mathrm{b}}$, Jasmine Ghuman M.D. ${ }^{\mathrm{b}}$, Ahmed Hanfy, M.D. ${ }^{\mathrm{b}}$, Joyce

Nimo-Boampong, M.D., M.B.A. ${ }^{\mathrm{c}}$, Sirri Atanga, M.D. ${ }^{\mathrm{d}}$, Rajkumar Doshi, M.D., M.P.H. ${ }^{\mathrm{b}}$,

Sostanie Enoru, M.D. ${ }^{\mathrm{e}}$ and Nageshwara Gullapalli, M.D., M.P.H. ${ }^{\mathrm{b}}$

[a] Department of Medicine, Icahn School of Medicine at Mount Sinai (Queens Hospital), Queens, New York, NY, United States

[b] Department of Internal Medicine, University of Nevada Reno School of Medicine, Reno, Nevada, United States

[c] Department of Internal Medicine, Warren Alpert Medical School of Brown University, Providence, Rhode Island, United States

[d] Department of Medicine, United Health Services Wilson Medical Center, Johnson City, NY, United States

[e] Department of Cardiovascular Disease, SUNY Downstate Health Science University, Brooklyn, New York, NY, United States

Running Title: Cardiac adverse effects of immune-checkpoint inhibitors

\section{Corresponding author:}

Bryce D. Beutler

Department of Internal Medicine

University of Nevada Reno School of Medicine

1155 Mill Street, W-11

Reno, NV 89502. USA

Phone: 775-327-5174

Email: brycebeutler@hotmail.com

Author Contributions: * indicates equal contribution to the study.

DA conceived the study hypothesis. NN and DA designed the study and performed the systematic search, study selection and data extraction. NN analyzed the data. All authors contributed to the interpretation of the data, writing and critical editing of the manuscript.

Protocol Registration: None

Funding: The study was not supported by any funding sources

Conflicts of interest: None declared. 


\begin{abstract}
Background

Immune checkpoint inhibitors (ICIs) are novel therapeutic agents used for various types of cancer. ICIs have revolutionized cancer treatment and improved clinical outcomes among cancer patients. However, immune-related adverse effects of ICI therapy are common. Cardiovascular immune-related adverse events (irAEs) are rare but potentially life-threatening complications. We aimed to estimate the incidence of cardiovascular irAEs among patients undergoing ICI therapy for various malignancies.
\end{abstract}

\title{
Methods
}

We conducted this systematic review and meta-analysis by searching PubMed, Cochrane CENTRAL, Web of Science, and SCOPUS databases for relevant interventional trials reporting cardiovascular irAEs. We performed a single-arm meta-analysis using OpenMeta [Analyst] software of the following outcomes: myocarditis, pericardial effusion, heart failure, cardiomyopathy, atrial fibrillation, myocardial infarction, and cardiac arrest. We assessed the heterogeneity using the $\mathrm{I}^{2}$ test and managed to solve it with Cochrane's leave-one-out method. The risk of bias was performed with the Cochrane's risk of bias tool.

\section{Results}

A total of 26 studies were included. The incidence of irAEs follows: myocarditis: $0.5 \%$ (95\% CI [0.1\%-0.9\%]); pericardial effusion: $0.5 \%$ (95\% CI [0.1\%-1.0\%]); heart failure: $0.3 \%$ (95\% CI [0.0\%-0.5\%]); cardiomyopathy: $0.3 \%$ (95\% CI [-0.1\%-0.6\%]); atrial fibrillation: $7.6 \%$ (95\% CI [1.0\%-14.1\%]); myocardial infarction: $0.4 \%$ (95\% CI [0.0\%-0.7\%]); and cardiac arrest: $0.4 \%$ (95\% CI $[0.1 \%-0.8 \%])$.

\section{Conclusion}


The most common cardiovascular irAEs were atrial fibrillation, myocarditis, and pericardial effusion. Although rare, data from post market surveillance will provide estimates of the longterm prevalence and prognosis in patients with ICI-associated cardiovascular complications.

Keywords: atrial fibrillation; cancer; immune checkpoint inhibitors; immunotherapy; cardiovascular adverse effects 
medRxiv preprint doi: https://doi.org/10.1101/2020.06.01.20119719; this version posted June 2, 2020. The copyright holder for this preprint (which was not certified by peer review) is the author/funder, who has granted medRxiv a license to display the preprint in perpetuity.

It is made available under a CC-BY 4.0 International license.

\section{Introduction}

Immune checkpoint inhibitors (ICIs) have demonstrated remarkable efficacy in various malignancies, including lung cancer, melanoma, Hodgkin's lymphoma, bladder cancer, and microsatellite instability (1). ICIs exert their effects through blocking inhibitory receptors on tumor cells (programmed cell death 1 ligand-1 [PD-L1]) $(2,3)$ or T-lymphocytes (programmed cell death protein-1 [PD-1] or cytotoxic T lymphocyte-associated protein-4 [CTLA-4]) $(4,5)$. The blockade of these receptors activates the effector T cells to target neoplastic cells (2). Many studies have demonstrated significant survival benefits of ICIs (6-8) and over 1,200 trials are currently ongoing (9).

The mechanism of action of ICIs involves non-specific activation of the immune system (10). Consequently, autoimmune inflammatory reactions frequently occur; this can ultimately lead to a broad spectrum of immune-related adverse events (irAEs) affecting both on-target and off-target organs (11). Reactions involving the skin, gastrointestinal tract, and endocrine system are relatively common among cancer patients on ICIs $(12,13)$. Approximately $80 \%$ of patients treated with agents targeting CTLA-4, $70 \%$ of patients treated with anti-PD-1 drugs, and $40 \%$ of those treated with anti-PD-L1 agents develop irAEs $(13,14)$. Severe events are common and up to $40 \%$ of patients on ICIs require treatment discontinuation due to irAEs (10).

Cardiovascular irAEs are rare, but potentially life-threatening (15). Although the initial trials on ICIs did not assess myocardial activity, growing evidence from case reports, case series, and cohort studies have raised awareness of unexpected cardiac toxicities associated with ICI therapy (16-18). Dual therapy appears to markedly increase the risk of cardiovascular irAEs; using the Bristol-Myers Squibb safety database, the estimated rate of myocarditis in patients 
medRxiv preprint doi: https://doi.org/10.1101/2020.06.01.20119719; this version posted June 2, 2020. The copyright holder for this preprint (which was not certified by peer review) is the author/funder, who has granted medRxiv a license to display the preprint in perpetuity.

It is made available under a CC-BY 4.0 International license .

receiving combination immunotherapy (ipilimumab plus nivolumab) was $0.27 \%$ as compared to $0.06 \%$ in those receiving nivolumab monotherapy (18).

Data on other ICI-related cardiac toxicities are scarce. This study aims to provide highclass evidence on the incidence of ICI-related cardiovascular adverse events through a systematic review and meta-analysis.

\section{Methods}

This systematic review and meta-analysis complies with the Preferred Reporting Items for Systematic reviews and Meta-Analyses (PRISMA) statement (19) and Cochrane's Handbook of Systematic Reviews of Interventions (20).

\section{Eligibility criteria}

Our analysis included interventional trials involving patients receiving an ICI in which an adverse cardiovascular event was reported. We excluded the following: non-randomized trials, trials involving concurrent use of other anticancer interventions, animal studies, non-clinical studies, reviews, and meta-analyses. We also excluded studies without accessible data, conference abstracts, and studies for which there was no English language translation.

\section{Literature search}

We searched PubMed, Cochrane CENTRAL, SCOPUS, and Web of Science databases for possible included articles according to our eligibility criteria from May $1^{\text {st }}, 2020$ through May $15^{\text {th }}, 2020$. We retrieved articles using a combination of the following keywords:

"cardiotoxicity", “adverse", “events", “myocard*”, "pericard*”, "neoplasm”, "cancer", and "immune checkpoint inhibitor."

Study Selection, Data collection, and analysis

Screening of results 
medRxiv preprint doi: https://doi.org/10.1101/2020.06.01.20119719; this version posted June 2, 2020. The copyright holder for this preprint (which was not certified by peer review) is the author/funder, who has granted medRxiv a license to display the preprint in perpetuity.

It is made available under a CC-BY 4.0 International license .

We performed the screening of retrieved studies through two stages. The first stage involved the inclusion and exclusion of studies based on title and abstract review. Selected studies underwent full-text screening against the inclusion criteria. Studies that had a mismatch with a single inclusion criterion were excluded. We conducted another search through the references of the included trials to ensure that no trials were inadvertently excluded. We considered studies which included multiple treatment arms as separate studies based on the adverse event reporting and refer to them as first author last name, year of publication followed by $\mathrm{a}, \mathrm{b}$, or $\mathrm{c}$ in the forest plot diagrams and Table 1. Figure 1 shows a PRISMA flow chart of the literature search.

\section{Data extraction}

We used a data extraction form specifically designed for this study. Three main categories of data were extracted. The first category included baseline data about the study participants, such as patients' age, gender, cancer type, and drug administered and dose. The second category included different outcome endpoints for analysis (any reported cardiovascular adverse event). The third category involved data used to assess the risk of bias among the included studies.

Quality and risk of bias assessment

This systematic review and meta-analysis were conducted in accordance with the principles of the Grading of Recommendations, Assessment, Development, and Evaluations (GRADE). We included clinical trials only to ensure high-quality evidence. For assessment of the risk of bias, we used the Cochrane's Risk of Bias tool (21).

\section{Data synthesis}


medRxiv preprint doi: https://doi.org/10.1101/2020.06.01.20119719; this version posted June 2, 2020. The copyright holder for this preprint (which was not certified by peer review) is the author/funder, who has granted medRxiv a license to display the preprint in perpetuity.

It is made available under a CC-BY 4.0 International license.

The extracted data were restricted to dichotomous outcomes, as all the data for the analysis are adverse events expressed as events/total. Using the OpenMeta[Analyst] Software, the intended scores were pooled as risk ratios (RR), and the presence of heterogeneity was assessed using two main tests (22), the I-square test $\left(I^{2}\right)$ and the P-value of the Chi-square test. The analysis is said to be heterogeneous if values of $I^{2}>50 \%$ and $\mathrm{p}<0.1$ were present, according to the Cochrane Handbook (20). We performed the analysis of homogeneous data under a fixedeffects model, while heterogeneous data were analyzed under the random-effects model.

\section{Results}

\section{Summary of included studies}

We present the analysis of 4,622 cancer patients from 26 studies. Figure 1 presents a flow diagram of the number of studies at each stage of the study selction process. Males were slightly overrepresented as compared to females (2,420 [52.4\%] versus 2,202 [47.6\%]). The mean age was 63.7 years. Further details pertaining to study characteristics, cancer type, ICI administered, and demographic data are illustrated in Table 1.

Results of risk of bias

The overall risk of bias was high among the included studies. Studies reported various data regarding randomization of patients, allocation concealment, blinding of participants and personnel, blinding of outcome assessors, attrition bias, and selective reporting. The risk of bias status is summarized in Figure 2.

Results of analysis of outcomes

Incidence of myocarditis 
medRxiv preprint doi: https://doi.org/10.1101/2020.06.01.20119719; this version posted June 2, 2020. The copyright holder for this preprint (which was not certified by peer review) is the author/funder, who has granted medRxiv a license to display the preprint in perpetuity.

It is made available under a CC-BY 4.0 International license.

Twelve studies reported the incidence of myocarditis as a cardiovascular irAE. The overall effect estimate showed that the incidence of myocarditis was $0.5 \%$; the analysis was significant (95\% CI [0.1\%-0.9\%]) and homogeneous $\left(I^{2}=0 \%, \mathrm{P}=0.5\right)$.

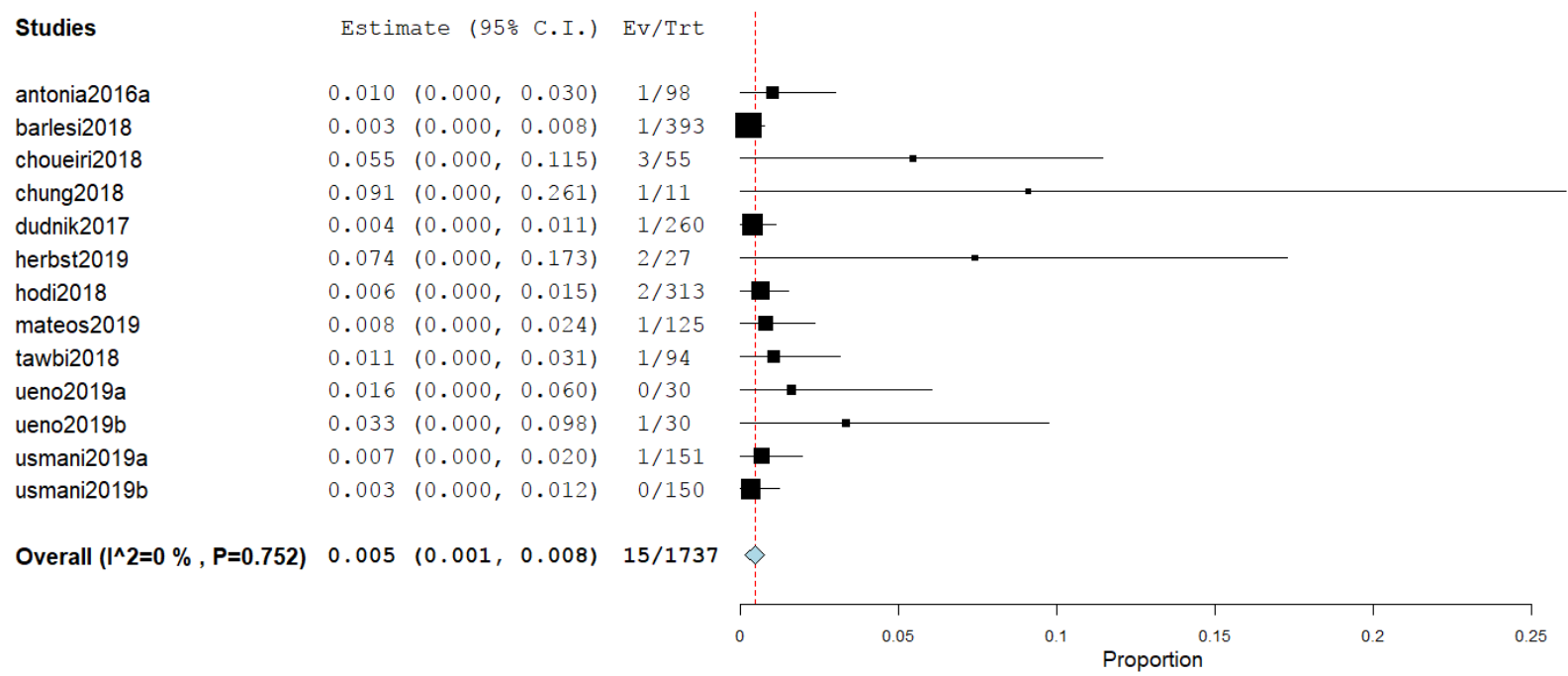

\section{Incidence of pericardial effusion}

Nine studies reported the incidence of pericardial effusion as a cardiovascular irAE. The overall effect estimate showed that the incidence of pericardial effusion was $0.5 \%$; the analysis was significant $(95 \% \mathrm{CI}[0.1 \%-1.0 \%])$ and homogeneous $\left(I^{2}=36.7 \%, \mathrm{P}=0.1\right)$.

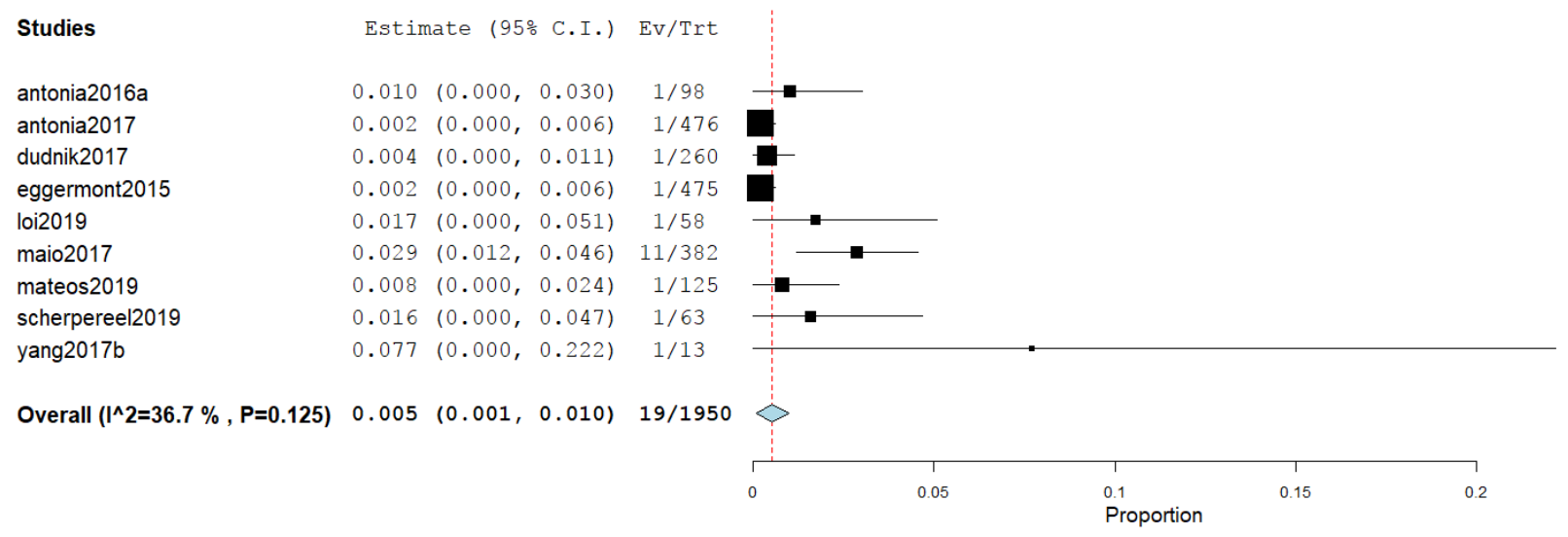

Incidence of heart failure 
Seven studies reported the incidence of heart failure as a cardiovascular irAE. The overall effect estimate showed that the incidence of heart failure was $0.3 \%$; the analysis was homogeneous $\left(I^{2}=0 \%, \mathrm{P}=0.1\right)$ but not significant $(95 \%$ CI $[0.0 \%-0.5 \%])$.

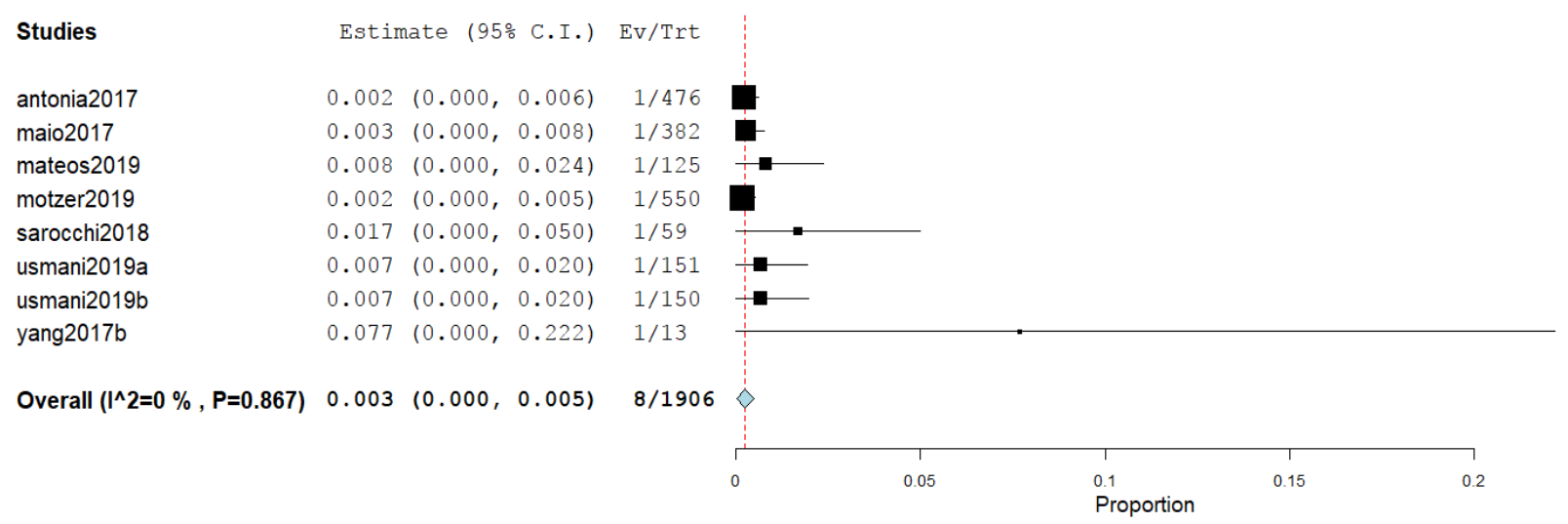

\section{Incidence of cardiomyopathy}

Five studies reported the incidence of cardiomyopathy as a cardiovascular irAE. The overall effect estimate showed that the incidence of cardiomyopathy was $0.3 \%$; the analysis was homogeneous $\left(I^{2}=0 \%, \mathrm{P}=0.6\right)$ but not significant $(95 \%$ CI $[-0.1 \%-0.6 \%])$.

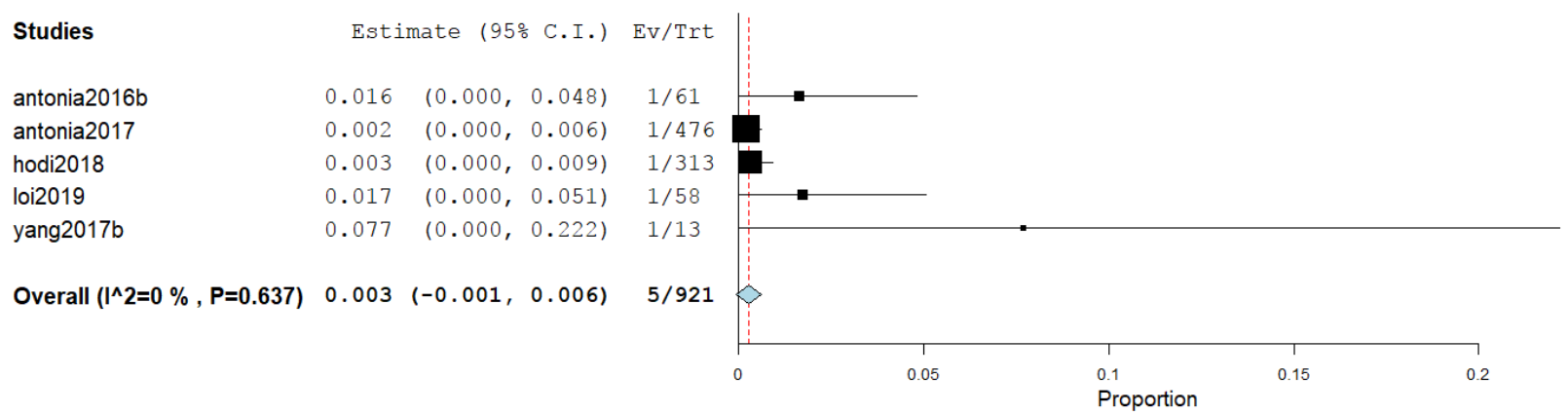

\section{Incidence of atrial fibrillation}

Four studies reported the incidence of atrial fibrillation as a cardiovascular irAE. The overall effect estimate showed that the incidence of atrial fibrillation was $7.6 \%$; the analysis was significant (95\% CI [1.0\%-14.1\%]) and heterogeneous $\left(I^{2}=0 \%, \mathrm{P}=0.6\right)$. Using Cochrane's leaveone-out method, we solved the heterogeneity by excluding one study (Bott et al). Homogeneous 
medRxiv preprint doi: https://doi.org/10.1101/2020.06.01.20119719; this version posted June 2, 2020. The copyright holder for this preprint (which was not certified by peer review) is the author/funder, who has granted medRxiv a license to display the preprint in perpetuity.

It is made available under a CC-BY 4.0 International license .

results revealed an incidence rate of atrial fibrillation of $4.6 \%$. The results were not significant $(95 \%$ CI $[-0.2 \%-9.4 \%])$.

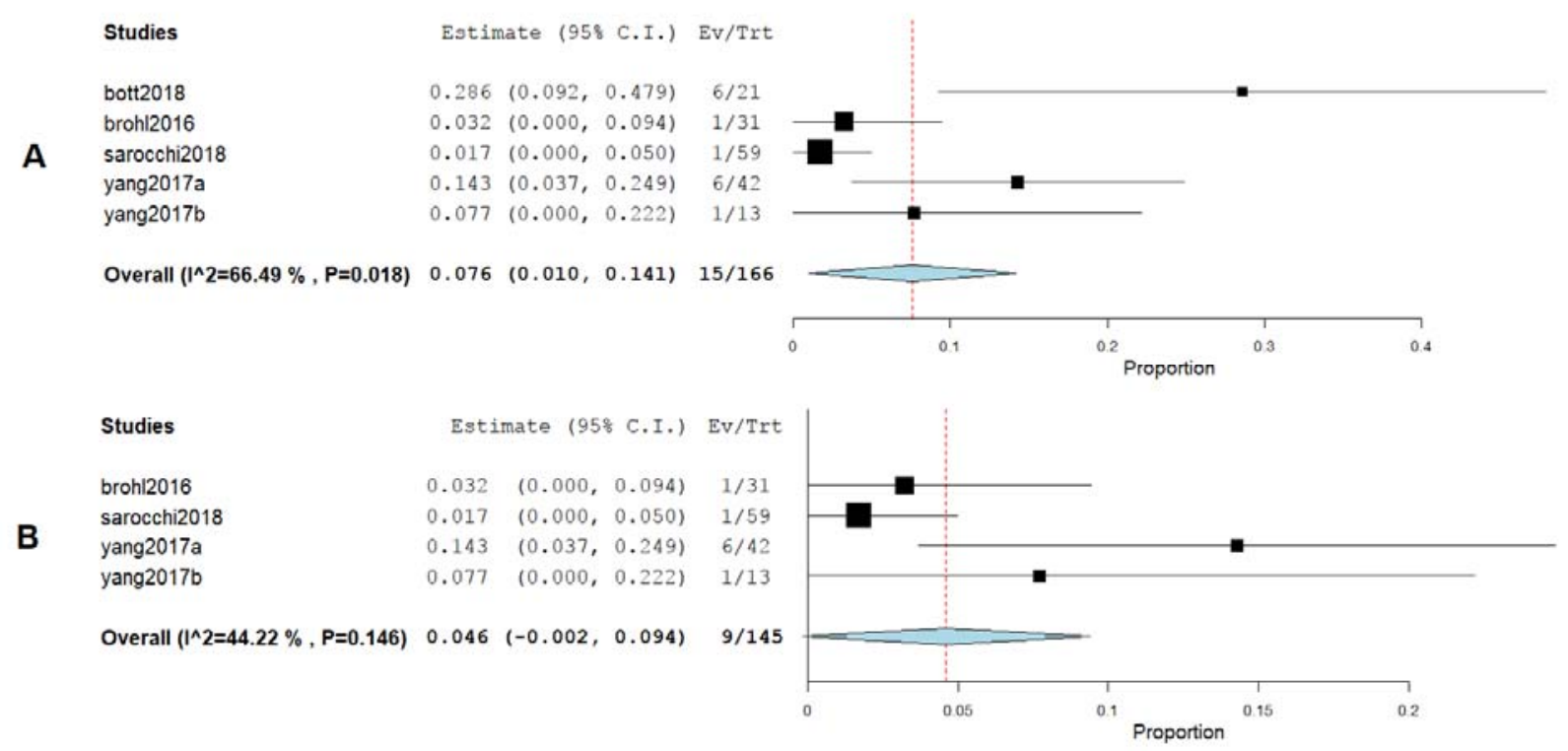

Incidence of myocardial infarction

Six studies reported the incidence of myocardial infarction as a cardiovascular irAE. The overall effect estimate showed that the incidence of MI was $0.4 \%$; the analysis was homogeneous $\left(I^{2}=0 \%, \mathrm{P}=0.1\right)$ but not significant $(95 \%$ CI $[0.0 \%-0.7 \%])$.

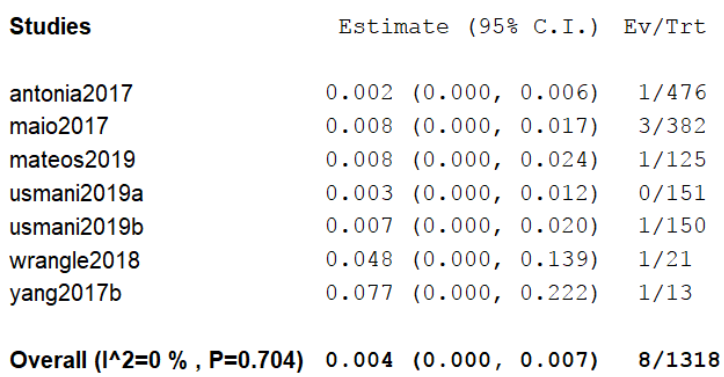

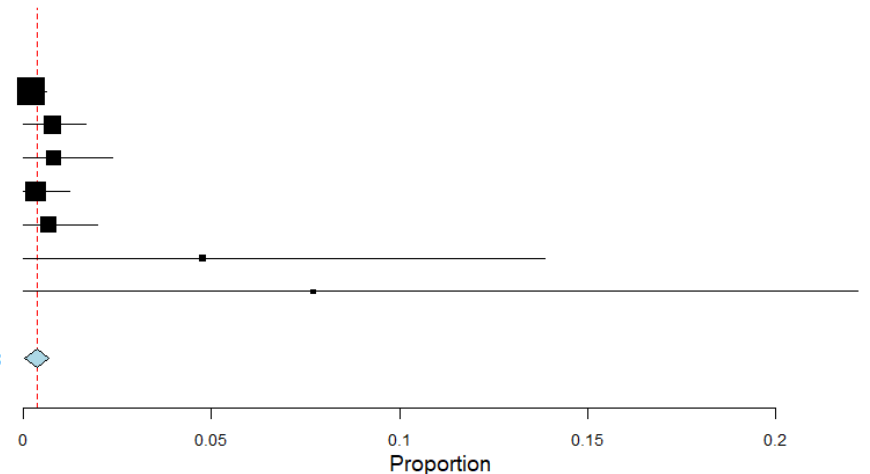

Incidence of cardiac arrest

Four studies reported the incidence of cardiac arrest as a cardiovascular irAE. The overall effect estimate showed that the incidence of cardiac arrest was $0.4 \%$; the analysis was significant 
medRxiv preprint doi: https://doi.org/10.1101/2020.06.01.20119719; this version posted June 2, 2020. The copyright holder for this preprint (which was not certified by peer review) is the author/funder, who has granted medRxiv a license to display the preprint in perpetuity.

It is made available under a CC-BY 4.0 International license.

\section{$(95 \% \mathrm{CI}[0.1 \%-0.8 \%])$ and homogeneous $\left(I^{2}=0 \%, \mathrm{P}=0.6\right)$}

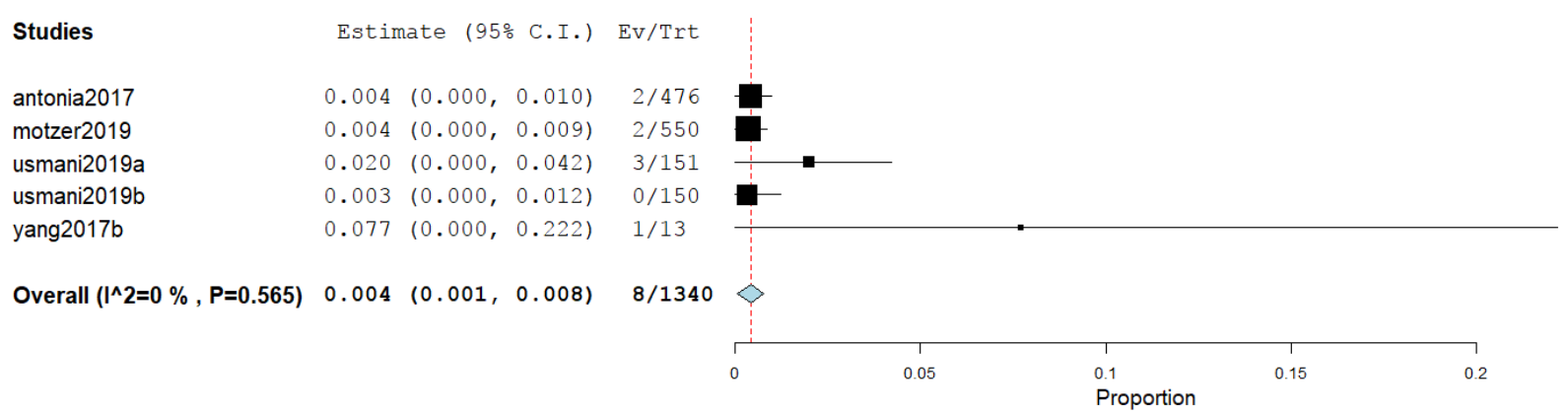


medRxiv preprint doi: https://doi.org/10.1101/2020.06.01.20119719; this version posted June 2, 2020. The copyright holder for this preprint (which was not certified by peer review) is the author/funder, who has granted medRxiv a license to display the preprint in perpetuity.

It is made available under a CC-BY 4.0 International license .

\section{Discussion}

Cardiotoxicity is a rare but potentially fatal adverse effect of ICI therapy. The incidence of cardiovascular irAEs remains to be established (23). Our meta-analysis of 26 studies including a total of 4,622 ICI-treated cancer patients showed that $0.5 \%$ of cancer patients treated with ICIs developed myocarditis, $0.3 \%$ developed heart failure, and $7.6 \%$ developed atrial fibrillation. In addition, pericardial effusion occurred in $0.5 \%$ of patients, cardiomyopathy in $0.3 \%$ of patients, myocardial infarction in $0.4 \%$ of patients, and cardiac arrest in $0.4 \%$ of patients. These results are relatively consistent as evidenced by the low level of statistical heterogeneity.

The underlying pathogenesis of cardiovascular irAEs has yet to be fully elucidated. However, several mechanisms have been proposed. The most frequently postulated mechanism underlying myocarditis is that T-lymphocytes could target an antigen common to both neoplastic tissue and the heart. Indeed, in a recent report by Johnson et al., the authors described a common high-frequency T-lymphocyte sequence found in both tumor and cardiac muscles (18).

Preclinical studies of mouse models have also shown that PD-1 and CTLA-4 deficiency is associated with myocarditis. The deletion of the PD-1 and CTLA-4 axes induces autoimmune myocarditis, indicating that the PD-1/PD-L1 interaction and CLTA-4 play important roles in protecting against T-lymphocyte-mediated inflammation (24-26). Injury usually occurs within first three months of initiating ICI; however, late presentation is not uncommon $(27,28)$.

T-lymphocyte-mediated inflammation may also be implicated in the pathogenesis of ICIrelated atrial fibrillation. In one recent case report, histopathologic analysis of a patient with atrial fibrillation displayed patchy infiltrations of lymphocytes in the sinoatrial and atrioventricular nodes (18); this suggests that T-lymphocytes are intricately involved in the development of atrial fibrillation and other ICI-induced conduction disorders. 
medRxiv preprint doi: https://doi.org/10.1101/2020.06.01.20119719; this version posted June 2, 2020. The copyright holder for this preprint (which was not certified by peer review) is the author/funder, who has granted medRxiv a license to display the preprint in perpetuity.

It is made available under a CC-BY 4.0 International license.

T-lymphocyte-related inflammatory processes are also suspected in pericardial effusion (29) and myocardial infarction (30). Lyon et al. suggested that the development of ICI-induced myocardial infarction could be due to the activation of an inflammatory reaction that triggers atherosclerotic coronary plaque formation and acute infarction. Conversely, Nykl et al. argued that the PD-1 inhibitory effect of ICIs leads to coronary vasospasm and ST-segment elevation. The mechanism by which coronary vasospasm develops is unclear but could be associated with systemic inflammatory response syndrome (21).

The incidence of cardiovascular irAEs is affected by many risk factors. Patients treated with combination therapy were more susceptible to cardiac complications as compared to those treated with ICI monotherapy (27). In addition, male patients are at higher risk of developing cardiovascular irAEs. A retrospective analysis showed that $77 \%$ of cases with ICI-related cardiac toxicity were males (26). In addition, another multicenter study found that 23 out of 35 irAEs (71\%) occurred in male patients (32). However, data is limited and based on retrospective analyses of a small number of cases (65 cases). Furthermore, concomitant cardiovascular disease is a potential risk factor for cardiovascular irAEs (33).

Cardiovascular irAEs are classified into four grades by the Society for Immunotherapy of Cancer (34). The management of patients with cardiovascular irAEs differs based on the grade and severity of the symptoms. Grade I is usually asymptomatic and requires neither treatment nor discontinuation of immunotherapy. Grade II is characterized by mild cardiac symptoms that should be controlled by holding cancer immunotherapy and management of the coexisting cardiac disease and its risk factors. Grade III cardiovascular symptoms are significant and require the withdrawal of ICI therapy as well as urgent initiation of high-dose prednisone (1-2 mg/kg). Grade IV cardiovascular irAEs are life-threatening conditions characterized by decompensated 
medRxiv preprint doi: https://doi.org/10.1101/2020.06.01.20119719; this version posted June 2, 2020. The copyright holder for this preprint (which was not certified by peer review) is the author/funder, who has granted medRxiv a license to display the preprint in perpetuity.

It is made available under a CC-BY 4.0 International license .

cardiac function with moderate-to-severe symptoms; corticosteroid therapy is the first-line treatment. The addition of intravenous immunoglobulins, infliximab, or anti-thymocyte globulin should be considered as second-line treatments for patients with grade IV cardiovascular irAEs $(10,34)$.

Long-term data regarding the prognosis of patients with cardiovascular irAEs are limited. However, the available findings suggest a high fatality rate. In a systematic review that included 99 patients with cardiovascular irAEs, the fatality rate was $35 \%(28,35)$. In addition, observational studies report a 50\% rate of major adverse cardiac events in ICI-associated myocarditis, which is significantly higher than that of non-ICI-related myocarditis $(36,37)$.

This study represents an attempt to estimate the overall incidence of cardiovascular irAEs in cancer patients receiving ICI therapy. The quality of the included studies ranged from low to moderate according to the Cochrane Risk of Bias Assessment tool (21). The main limitation of our analysis is that the included studies were not primarily designed to investigate the incidence of ICI-induced cardiac adverse events. In addition, there was a high risk of bias resulting from the difficultly in blinding and randomization of some studies. The definitions to determine adverse events were slightly different across all studies. We did not consider medication dose, which may influence the severity of adverse effects. It is also important to note that malignancy in and of itself is a risk factor for coronary artery disease and other cardiovascular comorbidities and hence it is difficult to differentiate a concomitant cardiovascular irAE (38). It is therefore reasonable to perform cardiovascular magnetic resonance to distinguish a pre-existing cardiovascular disease from a cardiovascular irAE $(36,38)$. Nevertheless, we believe this analysis provides a valuable framework for further studies on ICI-associated cardiovascular events. 
medRxiv preprint doi: https://doi.org/10.1101/2020.06.01.20119719; this version posted June 2, 2020. The copyright holder for this preprint (which was not certified by peer review) is the author/funder, who has granted medRxiv a license to display the preprint in perpetuity.

It is made available under a CC-BY 4.0 International license .

\section{Conclusion}

Cardiovascular irAEs are rare but potentially life-threatening complications that can occur in patients receiving ICI therapy. Our analysis revealed that the most frequent ICIassociated adverse events are atrial fibrillation, myocarditis, and pericardial effusion. Risk factors for cardiovascular irAEs include treatment with combination immunotherapy, male sex, and a history of cardiac disease. Data on the prognosis of cardiac irAEs are limited. Ongoing post-market surveillance is therefore imperative to characterize long-term risks and improve outcomes among patients receiving ICIs. 
medRxiv preprint doi: https://doi.org/10.1101/2020.06.01.20119719; this version posted June 2, 2020. The copyright holder for this preprint (which was not certified by peer review) is the author/funder, who has granted medRxiv a license to display the preprint in perpetuity.

It is made available under a CC-BY 4.0 International license .

\section{References}

1. Hirsch L, Zitvogel L, Eggermont A, Marabelle A. PD-Loma: a cancer entity with a shared sensitivity to the PD-1/PD-L1 pathway blockade. Nature Publishing Group; 2019.

2. Gulley JL, Rajan A, Spigel DR, Iannotti N, Chandler J, Wong DJ, et al. Avelumab for patients with previously treated metastatic or recurrent non-small-cell lung cancer (JAVELIN Solid Tumor): dose-expansion cohort of a multicentre, open-label, phase $1 \mathrm{~b}$ trial. The Lancet Oncology. 2017;18(5):599-610.

3. Choueiri TK, Larkin J, Oya M, Thistlethwaite F, Martignoni M, Nathan P, et al.

Preliminary results for avelumab plus axitinib as first-line therapy in patients with advanced clear-cell renal-cell carcinoma (JAVELIN Renal 100): an open-label, dose-finding and doseexpansion, phase $1 \mathrm{~b}$ trial. The lancet oncology. 2018;19(4):451-60.

4. Larkin J, Chiarion-Sileni V, Gonzalez R, Grob JJ, Cowey CL, Lao CD, et al. Combined nivolumab and ipilimumab or monotherapy in untreated melanoma. New England journal of medicine. 2015;373(1):23-34.

5. Wolchok JD, Chiarion-Sileni V, Gonzalez R, Rutkowski P, Grob J-J, Cowey CL, et al. Overall survival with combined nivolumab and ipilimumab in advanced melanoma. New England Journal of Medicine. 2017;377(14):1345-56.

6. Scherpereel A, Mazieres J, Greillier L, Lantuejoul S, Dô P, Bylicki O, et al. Nivolumab or nivolumab plus ipilimumab in patients with relapsed malignant pleural mesothelioma (IFCT1501 MAPS2): a multicentre, open-label, randomised, non-comparative, phase 2 trial. The Lancet Oncology. 2019;20(2):239-53.

7. Juergens RA, Hao D, Ellis PM, Tu D, Mates M, Kollmannsberger C, et al. A phase IB study of durvalumab with or without tremelimumab and platinum-doublet chemotherapy in 
medRxiv preprint doi: https://doi.org/10.1101/2020.06.01.20119719; this version posted June 2, 2020. The copyright holder for this preprint (which was not certified by peer review) is the author/funder, who has granted medRxiv a license to display the preprint in perpetuity.

It is made available under a CC-BY 4.0 International license.

advanced solid tumours: Canadian Cancer Trials Group Study IND226. Lung Cancer. 2020;143:1-11.

8. Antonia SJ, López-Martin JA, Bendell J, Ott PA, Taylor M, Eder JP, et al. Nivolumab alone and nivolumab plus ipilimumab in recurrent small-cell lung cancer (CheckMate 032): a multicentre, open-label, phase 1/2 trial. The Lancet Oncology. 2016;17(7):883-95.

9. Topalian SL. Targeting immune checkpoints in cancer therapy. Jama. 2017;318(17):1647-8.

10. Brahmer JR, Lacchetti C, Schneider BJ, Atkins MB, Brassil KJ, Caterino JM, et al. Management of immune-related adverse events in patients treated with immune checkpoint inhibitor therapy: American Society of Clinical Oncology Clinical Practice Guideline. Journal of clinical oncology: official journal of the American Society of Clinical Oncology. 2018;36(17):1714.

11. Postow MA, Sidlow R, Hellmann MD. Immune-related adverse events associated with immune checkpoint blockade. New England Journal of Medicine. 2018;378(2):158-68.

12. Schadendorf D, Wolchok JD, Hodi FS, Chiarion-Sileni V, Gonzalez R, Rutkowski P, et al. Efficacy and safety outcomes in patients with advanced melanoma who discontinued treatment with nivolumab and ipilimumab because of adverse events: a pooled analysis of randomized phase II and III trials. Journal of Clinical Oncology. 2017;35(34):3807.

13. Weber JS, Hodi FS, Wolchok JD, Topalian SL, Schadendorf D, Larkin J, et al. Safety profile of nivolumab monotherapy: a pooled analysis of patients with advanced melanoma. 2017. 14. Michot J, Bigenwald C, Champiat S, Collins M, Carbonnel F, Postel-Vinay S, et al. Immune-related adverse events with immune checkpoint blockade: a comprehensive review. European journal of cancer. 2016;54:139-48. 
medRxiv preprint doi: https://doi.org/10.1101/2020.06.01.20119719; this version posted June 2, 2020. The copyright holder for this preprint (which was not certified by peer review) is the author/funder, who has granted medRxiv a license to display the preprint in perpetuity.

It is made available under a CC-BY 4.0 International license.

15. Friedman CF, Proverbs-Singh TA, Postow MA. Treatment of the immune-related adverse effects of immune checkpoint inhibitors: a review. JAMA oncology. 2016;2(10):1346-53.

16. Yun S, Vincelette ND, Mansour I, Hariri D, Motamed S. Late onset ipilimumab-induced pericarditis and pericardial effusion: a rare but life threatening complication. Case reports in oncological medicine. 2015;2015.

17. Läubli H, Balmelli C, Bossard M, Pfister O, Glatz K, Zippelius A. Acute heart failure due to autoimmune myocarditis under pembrolizumab treatment for metastatic melanoma. Journal for immunotherapy of cancer. 2015;3(1):11.

18. Johnson DB, Balko JM, Compton ML, Chalkias S, Gorham J, Xu Y, et al. Fulminant myocarditis with combination immune checkpoint blockade. New England Journal of Medicine. 2016;375(18):1749-55.

19. Moher D, Liberati A, Tetzlaff J, Altman DG, Group P. Preferred reporting items for systematic reviews and meta-analyses: the PRISMA statement. PLoS med. 2009;6(7):e1000097.

20. Higgins JP, Thomas J, Chandler J, Cumpston M, Li T, Page MJ, et al. Cochrane handbook for systematic reviews of interventions: John Wiley \& Sons; 2019.

21. Higgins JP, Altman DG, Gøtzsche PC, Jüni P, Moher D, Oxman AD, et al. The Cochrane Collaboration's tool for assessing risk of bias in randomised trials. Bmj. 2011;343:d5928.

22. Higgins JP, Thompson SG, Deeks JJ, Altman DG. Measuring inconsistency in metaanalyses. Bmj. 2003;327(7414):557-60.

23. Ganatra S, Neilan TG. Immune checkpoint inhibitor $\square$ associated myocarditis. The oncologist. 2018;23(8):879. 
medRxiv preprint doi: https://doi.org/10.1101/2020.06.01.20119719; this version posted June 2, 2020. The copyright holder for this preprint (which was not certified by peer review) is the author/funder, who has granted medRxiv a license to display the preprint in perpetuity.

It is made available under a CC-BY 4.0 International license.

24. Love VA, Grabie N, Duramad P, Stavrakis G, Sharpe A, Lichtman A. CTLA-4 Ablation and Interleukin-12-Driven Differentiation Synergistically Augment Cardiac Pathogenicity of Cytotoxic T Lymphocytes. Circulation research. 2007;101(3):248-57.

25. Tivol EA, Borriello F, Schweitzer AN, Lynch WP, Bluestone JA, Sharpe AH. Loss of CTLA-4 leads to massive lymphoproliferation and fatal multiorgan tissue destruction, revealing a critical negative regulatory role of CTLA-4. Immunity. 1995;3(5):541-7.

26. Tarrio ML, Grabie N, Bu D-x, Sharpe AH, Lichtman AH. PD-1 protects against inflammation and myocyte damage in T cell-mediated myocarditis. The Journal of Immunology. 2012;188(10):4876-84.

27. Mahmood SS, Fradley MG, Cohen JV, Nohria A, Reynolds KL, Heinzerling LM, et al. Myocarditis in patients treated with immune checkpoint inhibitors. Journal of the American College of Cardiology. 2018;71(16):1755-64.

28. Escudier M, Cautela J, Malissen N, Ancedy Y, Orabona M, Pinto J, et al. Clinical features, management, and outcomes of immune checkpoint inhibitor-related cardiotoxicity. Circulation. 2017;136(21):2085-7.

29. Yang S AA. Cardiotoxicity associated with immune checkpoint inhibitors. Curr Probl Cancer. 2018;42:422e32.

30. Lyon AR YN, Battisti NML, Moslehi J, Larkin J. Immune checkpoint inhibitors and cardiovascular toxicity. Lancet Oncol. 2018;19:e447e58.

31. Nyk1 R, Fischer O, Vykoupil K, Taborsky M. A unique reason for coronary spasm causing temporary ST elevation myocardial infarction (inferior STEMI)-systemic inflammatory response syndrome after use of pembrolizumab. Archives of medical sciences Atherosclerotic diseases. 2017;2:e100. 
medRxiv preprint doi: https://doi.org/10.1101/2020.06.01.20119719; this version posted June 2, 2020. The copyright holder for this preprint (which was not certified by peer review) is the author/funder, who has granted medRxiv a license to display the preprint in perpetuity.

It is made available under a CC-BY 4.0 International license.

32. Mahrholdt H, Wagner A, Judd R, Sechtem U. Assessment of myocardial viability by cardiovascular magnetic resonance imaging. European heart journal. 2002;23(8):602-19.

33. Tadokoro T, Keshino E, Makiyama A, Sasaguri T, Ohshima K, Katano H, et al. Acute lymphocytic myocarditis with anti-PD-1 antibody nivolumab. Circulation: Heart Failure. 2016;9(10):e003514.

34. Puzanov I, Diab A, Abdallah K, Bingham C, Brogdon C, Dadu R, et al. Managing toxicities associated with immune checkpoint inhibitors: consensus recommendations from the Society for Immunotherapy of Cancer (SITC) Toxicity Management Working Group. Journal for immunotherapy of cancer. 2017;5(1):95.

35. Salem J-E, Manouchehri A, Moey M, Lebrun-Vignes B, Bastarache L, Pariente A, et al. Cardiovascular toxicities associated with immune checkpoint inhibitors: an observational, retrospective, pharmacovigilance study. The Lancet Oncology. 2018;19(12):1579-89.

36. Gräni C, Eichhorn C, Bière L, Murthy VL, Agarwal V, Kaneko K, et al. Prognostic value of cardiac magnetic resonance tissue characterization in risk stratifying patients with suspected myocarditis. Journal of the American College of Cardiology. 2017;70(16):1964-76.

37. Ammirati E, Cipriani M, Lilliu M, Sormani P, Varrenti M, Raineri C, et al. Survival and left ventricular function changes in fulminant versus nonfulminant acute myocarditis. Circulation. 2017;136(6):529-45.

38. Palaskas N, Lopez-Mattei J, Durand JB, Iliescu C, Deswal A. Immune checkpoint inhibitor myocarditis: pathophysiological characteristics, diagnosis, and treatment. J Am Heart Assoc. 2020;9(2):e013757. 
medRxiv preprint doi: https://doi.org/10.1101/2020.06.01.20119719; this version posted June 2, 2020. The copyright holder for this preprint (which was not certified by peer review) is the author/funder, who has granted medRxiv a license to display the preprint in perpetuity.

It is made available under a CC-BY 4.0 International license .

39. Gorgun GT, Samur MK, Cowens KB, Paula S, Bianchi G, et al. Lenalidomide enhances immune checkpoint blockade induced immune response in multiple myeloma. Clin Cancer Res. 2015;21(20):4607-4618. 
medRxiv preprint doi: https://doi.org/10.1101/2020.06.01.20119719; this version posted June 2, 2020. The copyright holder for this preprint (which was not certified by peer review) is the author/funder, who has granted medRxiv a license to display the preprint in perpetuity.

It is made available under a CC-BY 4.0 International license .
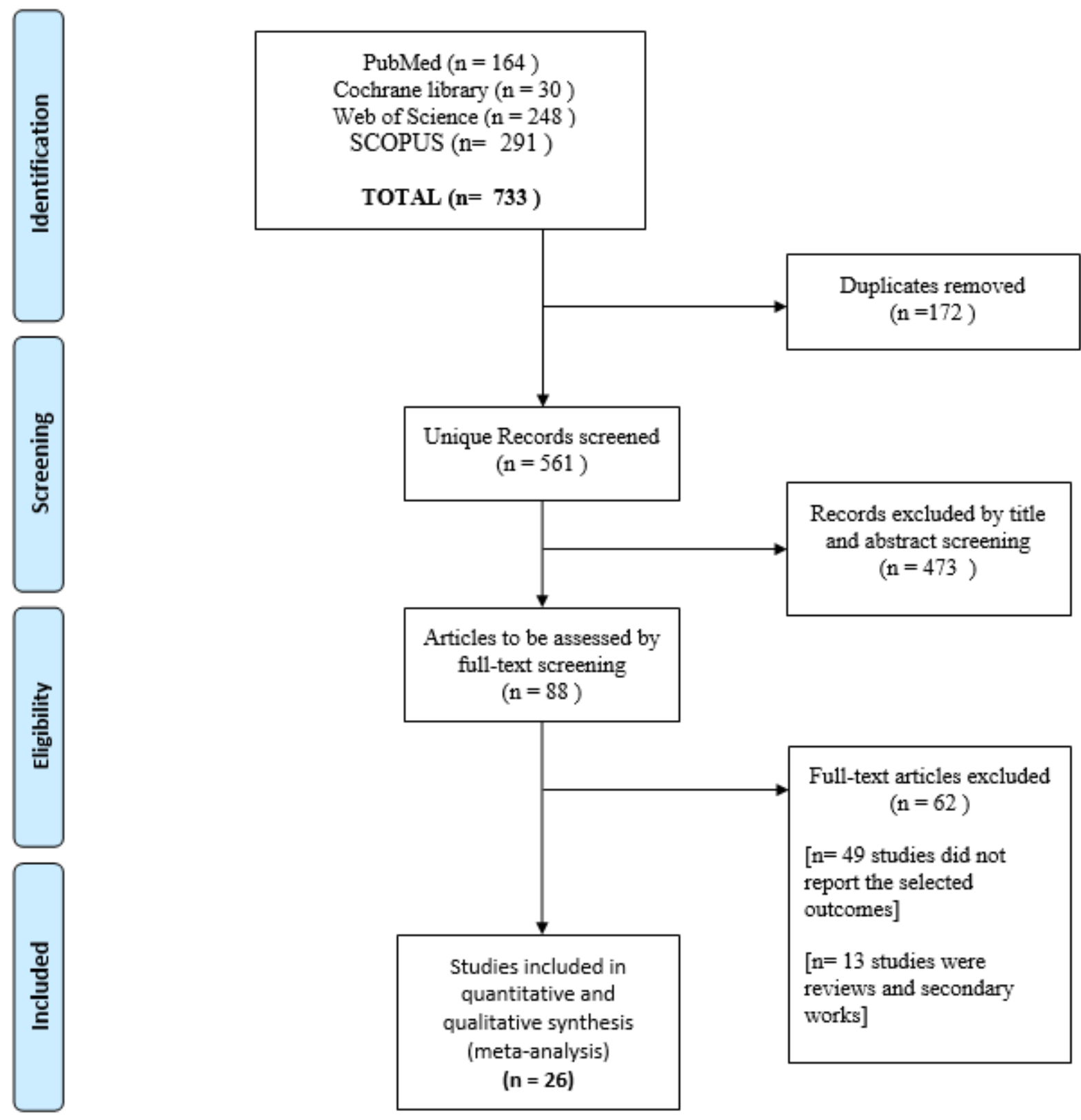

Figure 1. PRISMA diagram for our literature search 
medRxiv preprint doi: https://doi.org/10.1101/2020.06.01.20119719; this version posted June 2, 2020. The copyright holder for this preprint (which was not certified by peer review) is the author/funder, who has granted medRxiv a license to display the preprint in perpetuity.

It is made available under a CC-BY 4.0 International license .
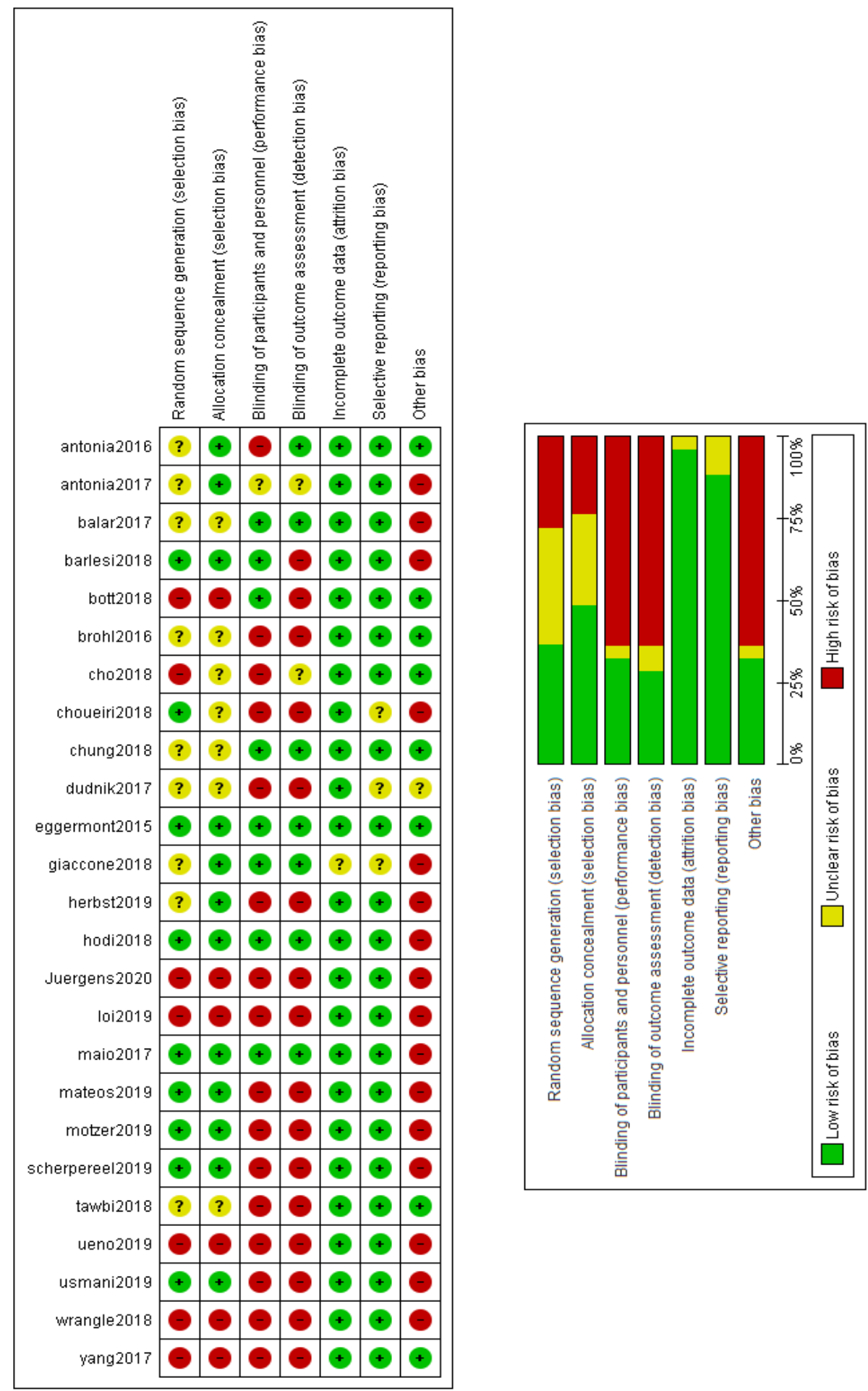

Figure 2: Results of risk of bias assessment among included trials. 
medRxiv preprint doi: https://doi.org/10.1101/2020.06.01.20119719; this version posted June 2, 2020. The copyright holder for this preprint (which was not certified by peer review) is the author/funder, who has granted medRxiv a license to display the preprint in perpetuity.

It is made available under a CC-BY 4.0 International license. 
Table 1: Summary of baseline characteristics of included studies.

\begin{tabular}{|c|c|c|c|c|c|c|c|c|c|}
\hline Study & $\mathbf{N}$ & ICI & Cancer type & $\begin{array}{l}\text { Males, } n \\
\quad(\%)\end{array}$ & $\begin{array}{l}\text { Median } \\
\text { age } \\
\text { (range), } \\
\text { years }\end{array}$ & $\begin{array}{l}\text { Median } \\
\text { follow-up } \\
\text { (range), } \\
\text { months }\end{array}$ & $\begin{array}{c}\text { Race } \\
- \\
\text { Asian }\end{array}$ & $\begin{array}{c}\text { Race } \\
- \\
\text { Black }\end{array}$ & $\begin{array}{l}\text { Tobacco } \\
\text { users }\end{array}$ \\
\hline $\begin{array}{l}\text { Antonia } \\
2016 a\end{array}$ & 98 & Nivolumab & $\begin{array}{l}\text { Small cell } \\
\text { carcinoma of the } \\
\text { lung }\end{array}$ & $61(62 \%)$ & $\begin{array}{c}63 \\
(57-68)\end{array}$ & $\begin{array}{l}10.07 \\
(\mathrm{NR})\end{array}$ & NR & $\begin{array}{c}3 \\
(3 \%)\end{array}$ & $95(97 \%)$ \\
\hline $\begin{array}{l}\text { Antonia } \\
2016 b\end{array}$ & 61 & $\begin{array}{l}\text { Nivolumab plus } \\
\text { ipilimumab }\end{array}$ & $\begin{array}{l}\text { Small cell } \\
\text { carcinoma of the } \\
\text { lung }\end{array}$ & $35(57 \%)$ & $\begin{array}{c}66 \\
(58-71)\end{array}$ & $\begin{array}{c}12.03 \\
(9.10-15.67)\end{array}$ & NR & $\begin{array}{c}1 \\
(2 \%)\end{array}$ & $57(93 \%)$ \\
\hline $\begin{array}{l}\text { Antonia } \\
2016 c\end{array}$ & 54 & $\begin{array}{l}\text { Nivolumab plus } \\
\text { ipilimumab }\end{array}$ & $\begin{array}{l}\text { Small cell } \\
\text { carcinoma of the } \\
\text { lung }\end{array}$ & $32(59 \%)$ & $\begin{array}{c}61 \\
(56-65)\end{array}$ & $\begin{array}{c}8.68( \\
8.27-9.6)\end{array}$ & NR & 0 & $48(89 \%)$ \\
\hline $\begin{array}{l}\text { Antonia } \\
2017\end{array}$ & 476 & Durvalumab & $\begin{array}{l}\text { Stage III non- } \\
\text { small cell lung } \\
\text { cancer }\end{array}$ & $334(70.2 \%)$ & $64(\mathrm{NR})$ & $\begin{array}{c}14.5 \\
(0.2-29.9)\end{array}$ & $\begin{array}{c}120 \\
(25.2 \\
\%)\end{array}$ & $\begin{array}{c}12 \\
(2.5 \%)\end{array}$ & $433(91 \%)$ \\
\hline Balar 2017 & 370 & $\begin{array}{l}\text { Pembrolizumab } \\
\text { plus cisplatin }\end{array}$ & $\begin{array}{l}\text { Advanced, } \\
\text { unresectable } \\
\text { metastatic } \\
\text { urothelial cancer }\end{array}$ & $286(77 \%)$ & $\begin{array}{c}74 \\
(34-94)\end{array}$ & $\begin{array}{c}5 \\
(30-8.6)\end{array}$ & NR & NR & NR \\
\hline Barlesi 2018 & 393 & Avelumab & $\begin{array}{l}\text { Advanced non- } \\
\text { small-cell lung } \\
\text { cancer }\end{array}$ & $269(68 \%)$ & $\begin{array}{c}64 \\
(59-70)\end{array}$ & $\begin{array}{c}18.9 \\
(\text { IQR 13.2-23) }\end{array}$ & $\begin{array}{c}102 \\
(26 \%)\end{array}$ & $\begin{array}{c}5 \\
(1 \%)\end{array}$ & $324(82 \%)$ \\
\hline Bott 2018 & 21 & Nivolumab & $\begin{array}{l}\text { Resectable non- } \\
\text { small cell lung } \\
\text { cancer }\end{array}$ & $10(48 \%)$ & $\begin{array}{c}67 \\
(55-84)\end{array}$ & $\begin{array}{c}1.1 \\
(0.57-1.13)\end{array}$ & NR & NR & $18(86 \%)$ \\
\hline Brohl 2016 & 31 & $\begin{array}{l}\text { Ipilimumab plus } \\
\text { peginterferon }\end{array}$ & $\begin{array}{l}\text { Unresectable } \\
\text { melanoma }\end{array}$ & $\begin{array}{c}18 \\
(58.1 \%)\end{array}$ & $\begin{array}{c}65 \\
(38-83)\end{array}$ & $\begin{array}{c}35.8 \\
(19.7-50.2)\end{array}$ & NR & NR & NR \\
\hline Cho 2018 & 33 & Pembrolizumab & $\begin{array}{l}\text { Relapsed } \\
\text { thymic epithelial } \\
\text { tumor }\end{array}$ & $\begin{array}{c}21 \\
(63.6 \%)\end{array}$ & $\begin{array}{c}57 \\
(26-78)\end{array}$ & $\begin{array}{l}14.9 \\
(\text { IQR } 6.25- \\
20.7)\end{array}$ & NR & NR & NR \\
\hline $\begin{array}{l}\text { Choueiri } \\
2018\end{array}$ & 55 & $\begin{array}{l}\text { Avelumab plus } \\
\text { axitinib }\end{array}$ & $\begin{array}{l}\text { Advanced clear } \\
\text { cell renal cell } \\
\text { carcinoma }\end{array}$ & $\begin{array}{c}42 \\
(76 \%)\end{array}$ & $\begin{array}{c}60 \\
(55-68)\end{array}$ & $\begin{array}{c}13 \\
(9.35-14.02)\end{array}$ & $\begin{array}{c}6 \\
(11 \%)\end{array}$ & $\begin{array}{c}3 \\
(6 \%)\end{array}$ & NR \\
\hline
\end{tabular}




\begin{tabular}{|c|c|c|c|c|c|c|c|c|c|}
\hline Chung 2018 & 11 & $\begin{array}{l}\text { p53MVA } \\
\text { vaccine } \\
\text { combined with } \\
\text { pembrolizumab }\end{array}$ & $\begin{array}{l}\text { Advanced breast, } \\
\text { pancreatic, } \\
\text { hepatocellular, or } \\
\text { head and neck } \\
\text { cancer }\end{array}$ & NR & NR & $\begin{array}{c}16.26(15.42- \\
17.27)\end{array}$ & NR & NR & NR \\
\hline $\begin{array}{l}\text { Dudnik } \\
2017\end{array}$ & 260 & Nivolumab & $\begin{array}{l}\text { Non-small cell } \\
\text { lung cancer }\end{array}$ & $\begin{array}{c}176 \\
(68 \%)\end{array}$ & $\begin{array}{c}67 \\
(41-99)\end{array}$ & $\begin{array}{c}8.4 \\
(2-16.8)\end{array}$ & NR & NR & $197(76 \%)$ \\
\hline $\begin{array}{l}\text { Eggermont } \\
2015\end{array}$ & 475 & Ipilimumab & $\begin{array}{l}\text { High-risk stage III } \\
\text { melanoma }\end{array}$ & $\begin{array}{l}296 \\
(62 \%)\end{array}$ & $\begin{array}{c}51 \\
(20-84)\end{array}$ & $\begin{array}{c}7.5 \\
(7-11.4)\end{array}$ & NR & NR & NR \\
\hline $\begin{array}{l}\text { Giaccone } \\
2018\end{array}$ & 40 & Pembrolizumab & $\begin{array}{l}\text { Thymic } \\
\text { carcinoma }\end{array}$ & $\begin{array}{c}28 \\
(70 \%)\end{array}$ & $\begin{array}{c}57 \\
(25-80)\end{array}$ & $\begin{array}{c}8.4 \\
(2-16.8)\end{array}$ & $\begin{array}{c}4 \\
(10 \%)\end{array}$ & $\begin{array}{c}2 \\
(5 \%)\end{array}$ & NR \\
\hline Herbst 2019 & 27 & $\begin{array}{l}\text { Ramucirumab } \\
\text { plus } \\
\text { pembrolizumab }\end{array}$ & $\begin{array}{l}\text { Advanced non- } \\
\text { small-cell lung } \\
\text { cancer }\end{array}$ & $\begin{array}{c}21 \\
(78 \%)\end{array}$ & $\begin{array}{c}65 \\
(56-72)\end{array}$ & $\begin{array}{c}33.3 \\
\text { (IQR 27.7- } \\
39.2 \text { ) }\end{array}$ & $\mathrm{NR}$ & $\begin{array}{c}1 \\
(4 \%)\end{array}$ & $26(96 \%)$ \\
\hline Hodi 2018 & 313 & $\begin{array}{l}\text { Nivolumab plus } \\
\text { ipilimumab }\end{array}$ & $\begin{array}{l}\text { Advanced } \\
\text { melanoma }\end{array}$ & NR & NR & $\begin{array}{c}20 \\
\text { (IQR } 14-26)\end{array}$ & NR & NR & NR \\
\hline $\begin{array}{l}\text { Juergens } \\
2020\end{array}$ & 136 & $\begin{array}{l}\text { Durvalumab } \\
\text { with or without } \\
\text { tremelimumab } \\
\text { and platinum- } \\
\text { doublet }\end{array}$ & $\begin{array}{l}\text { Lung cancer } \\
\text { (unspecified) }\end{array}$ & $\begin{array}{c}67 \\
(49 \%)\end{array}$ & $\begin{array}{c}61.9 \\
(30.1- \\
83.2)\end{array}$ & $\begin{array}{l}32.8 \\
\text { (IQR 28.1- } \\
33.6)\end{array}$ & $8(6 \%)$ & $\begin{array}{c}1 \\
(1 \%)\end{array}$ & NR \\
\hline Loi 2019 & 58 & $\begin{array}{l}\text { Pembrolizumab } \\
\text { plus } \\
\text { trastuzumab in } \\
\text { trastuzumab }\end{array}$ & $\begin{array}{l}\text { Lung cancer } \\
\text { (unspecified) }\end{array}$ & 0 & $\begin{array}{c}52 \\
(43-92)\end{array}$ & $\begin{array}{c}46.9 \\
(48-\mathrm{NR})\end{array}$ & NR & NR & NR \\
\hline Maio 2017 & 382 & Tremelimumab & $\begin{array}{l}\text { Malignant } \\
\text { mesothelioma }\end{array}$ & $\begin{array}{c}283 \\
(74 \%)\end{array}$ & $\begin{array}{c}66 \\
(60-72)\end{array}$ & $\begin{array}{c}19.61 \\
(0.23-26.48)\end{array}$ & $\begin{array}{c}7 \\
(2 \%)\end{array}$ & $\begin{array}{c}3 \\
(<1 \%)\end{array}$ & NR \\
\hline Mateos 2019 & 125 & $\begin{array}{l}\text { Pembrolizumab } \\
\text { plus } \\
\text { pomalidomide } \\
\text { and } \\
\text { dexamethasone }\end{array}$ & $\begin{array}{l}\text { Multiple } \\
\text { myeloma }\end{array}$ & $\begin{array}{c}77 \\
(62 \%)\end{array}$ & $\begin{array}{c}65 \\
(60-72)\end{array}$ & $\begin{array}{c}25.7 \\
\text { (IQR 25.6- } \\
25.8)\end{array}$ & NR & NR & NR \\
\hline Motzer 2019 & 550 & $\begin{array}{l}\text { Nivolumab plus } \\
\text { ipilimumab }\end{array}$ & $\begin{array}{l}\text { Advanced renal } \\
\text { cell carcinoma }\end{array}$ & NR & NR & $\begin{array}{c}2 \\
(1-3)\end{array}$ & NR & NR & NR \\
\hline $\begin{array}{l}\text { Sarocchi } \\
2018\end{array}$ & 59 & Nivolumab & $\begin{array}{l}\text { Advanced non- } \\
\text { small cell lung }\end{array}$ & 41 (NR) & $\begin{array}{c}69 \\
(44-81)\end{array}$ & $\begin{array}{c}8.1 \\
\text { (IQR 4.5-10.9) }\end{array}$ & NR & NR & $\begin{array}{c}51 \\
(86 \%)\end{array}$ \\
\hline
\end{tabular}




\begin{tabular}{|c|c|c|c|c|c|c|c|c|c|}
\hline $\begin{array}{l}\text { Scherpereel } \\
2019\end{array}$ & 63 & $\begin{array}{l}\text { Nivolumab or } \\
\text { nivolumab plus } \\
\text { ipilimumab }\end{array}$ & $\begin{array}{l}\text { cancer } \\
\text { Relapsed } \\
\text { malignant pleural } \\
\text { mesothelioma }\end{array}$ & $\begin{array}{c}47 \\
(75 \%)\end{array}$ & $\begin{array}{c}72 \cdot 3 \\
(32 \cdot 5- \\
87)\end{array}$ & $\begin{array}{c}32.4 \\
(I Q R \text { 13.4- } \\
\text { 36.3) }\end{array}$ & NR & NR & $\begin{array}{c}34 \\
(54 \%)\end{array}$ \\
\hline Tawbi 2018 & 94 & $\begin{array}{l}\text { Nivolumab plus } \\
\text { ipilimumab }\end{array}$ & $\begin{array}{l}\text { Melanoma with } \\
\text { brain metastases }\end{array}$ & $\begin{array}{c}65 \\
(69 \%)\end{array}$ & $\begin{array}{c}59 \\
(22-81)\end{array}$ & NR & NR & NR & NR \\
\hline Ueno 2019a & 30 & $\begin{array}{l}\text { Nivolumab } \\
\text { alone }\end{array}$ & $\begin{array}{l}\text { Unresectable or } \\
\text { recurrent biliary } \\
\text { tract cancer }\end{array}$ & NR & NR & $\begin{array}{c}20.1 \\
\text { (IQR 19.6- } \\
20.3)\end{array}$ & NR & NR & NR \\
\hline Ueno 2019b & 30 & $\begin{array}{l}\text { Nivolumab in } \\
\text { combination } \\
\text { with cisplatin }\end{array}$ & $\begin{array}{l}\text { Unresectable or } \\
\text { recurrent biliary } \\
\text { tract cancer }\end{array}$ & NR & NR & $\begin{array}{c}14 \\
(6-N R)\end{array}$ & NR & NR & NR \\
\hline $\begin{array}{l}\text { Usmani } \\
\text { 2019a }\end{array}$ & 151 & Pembrolizumab & $\begin{array}{l}\text { Multiple } \\
\text { myeloma }\end{array}$ & $\begin{array}{c}70 \\
(46 \%)\end{array}$ & $\begin{array}{c}74 \\
(70-79)\end{array}$ & $\begin{array}{c}5.1 \\
\text { (IQR 3.4-7) }\end{array}$ & NR & NR & NR \\
\hline $\begin{array}{l}\text { Usmani } \\
\text { 2019b }\end{array}$ & 150 & Lenalidomide $^{+}$ & $\begin{array}{l}\text { Multiple } \\
\text { myeloma }\end{array}$ & $\begin{array}{c}71 \\
(47 \%)\end{array}$ & $\begin{array}{c}74 \\
(70-78\end{array}$ & $\begin{array}{c}8.2 \\
\text { (IQR 7-14) }\end{array}$ & NR & NR & NR \\
\hline $\begin{array}{l}\text { Wrangle } \\
2018\end{array}$ & 21 & $\begin{array}{l}\text { ALT-803, an IL- } \\
15 \text { superagonist, } \\
\text { in combination } \\
\text { with nivolumab }\end{array}$ & $\begin{array}{l}\text { Metastatic non- } \\
\text { small cell lung }\end{array}$ & $\begin{array}{c}15 \\
(71 \%)\end{array}$ & $\begin{array}{c}55 \\
(46-67)\end{array}$ & $\begin{array}{c}6.6 \\
\text { (IQR 3.4-9.6) }\end{array}$ & NR & NR & $\begin{array}{c}12 \\
(57 \%)\end{array}$ \\
\hline Yang 2017a & 42 & $\begin{array}{l}\text { Preoperative } \\
\text { chemotherapy }\end{array}$ & $\begin{array}{l}\text { Non-small cell } \\
\text { lung cancer }\end{array}$ & $\begin{array}{c}21 \\
(50)\end{array}$ & NR & $\begin{array}{c}6.6 \\
\text { (IQR 3.4-9.6) }\end{array}$ & NR & $\begin{array}{c}7 \\
(17)\end{array}$ & NR \\
\hline Yang 2017b & 13 & Ipilimumab & $\begin{array}{l}\text { Non-small cell } \\
\text { lung cancer }\end{array}$ & $\begin{array}{c}5 \\
(38)\end{array}$ & NR & $\begin{array}{c}6.9 \\
\text { (IQR 5.5-12.0) }\end{array}$ & NR & $\begin{array}{c}3 \\
(23)\end{array}$ & NR \\
\hline
\end{tabular}

Abbreviations: $\mathrm{ICI}=$ immune checkpoint inhibitor; $\mathrm{NR}=$ not reported. Data are median (range) or N (\%) unless otherwise specified. NR: not reported.

${ }^{+}$Lenalidomide is typically considered an immunomodulator, but may also serve as an ICI [39]. 